\title{
Research on the "Trinity" Educational System of Journalism
}

\author{
Nie Jinglei ${ }^{1, a^{*}}$ \\ ${ }^{1}$ Department of Journalism and Communication, Ningbo Institute of Technology, Zhejiang University, Ningbo, \\ Zhejiang, China \\ a*njl215@126.com
}

\begin{abstract}
The party and the country attach great importance to the training of journalism professionals, and the training of journalism professionals adopts the "Trinity" education system. "Trinity" refers to the establishment of a collaborative development model of ideological and political education, professional ethics education, and professional knowledge education in the process of training journalism professionals, and an innovative education system for journalism. "Three in One" is the core content of journalism talent training, "One in One" is the main mode of training talent in journalism, and "Three in One" is the innovation and breakthrough of the journalism professional education system.
\end{abstract}

Keywords: Journalism, trinity, educational system

\section{新闻学“三位一体”育人体系研究 \\ 聂晶䂞 $1, a^{*}$}

1 浙大宁波理工学院新闻与传播学系, 宁波, 浙江, 中国

njl215@126.com

\section{摘要}

党和国家高度重视新闻学专业人才的培养,新闻学专业人才的培养采用 “三位一体” 的育人体系。“三位一体” 指的是在新闻学专业人才培养过程中，着重构建思想政治教育、职业道德教育、专业知识教育协同发展模式， 创新新闻学专业的育人体系。“三位” 是新闻学人才培养的核心内容, “一体” 是新闻学人才培养的主要模式, “三位一体” 是新闻学专业育人体系的创新与突破。

关键词: 新闻学, 三位一体，育人体系

\section{1. 前言}

新闻学专业是实践性、操作性非常强的专业，与 媒体行业的联系非常紧密。新闻学专业培养的人才, 在未来的工作岗位上担负着媒体内容 “把关” 的重任。 什么样的事件值得采访与报道? 什么样的内容适合 在大众媒体上广泛传播? 什么样的信息必须过滤掉? 新闻学专业思想政治建设如何进行、职业道德如何培 养、专业知识如何获取? 这一系列的核心问题关系到 新闻学专业育人体系的构建与完善, 必须一一回答、 一一解决。

\section{2. 新闻学 “三位一体” 育人体系的提出}

党和国家高度重视新闻学专业人才的培养, 教育 部、中共中央宣传部专门就此制定了相关文件。2018 年 9 月 17 日, 教育部、中共中央宣传部联合下发了 《教育部 中共中央宣传部关于提高高校新闻传播人 才培养能力实施卓越新闻传播人才教育培养计划 2.0
的意见》(教高〔2018〕7 号)，文件指出：“强化思想 引领和价值塑造, 构建思想政治教育、职业道德教育、 专业知识教育 “三位一体” 新闻传播育人体系。”由此 可以得知, 新闻学 “三位一体” 育人体系是由国家相 关主管部门提出的，政治站位高、指导性强、引领作 用大。新闻学 “三位一体” 育人体系融人才培养和人 才使用于一体，涵盖了前期的人才培养和后期的人才 使用两个方面、两个步骤。

在前期的人才培养过程中, 教育主管部门要整体规 划、统一部署、协调一致。高等院校要承担起人才培养 的重担, 提前规划、突出重点、具体实施, 为媒体行业 培养出优秀的专业人才。在后期的人才使用过程中，各 级宣传部门要发挥引领作用, 各类媒体行业要发挥新闻 传播 “主战场”的核心作用，对高校培养的新闻传播专 业人才进行大检验。各种媒体的实践演练是检验新闻学 专业人才水平的主战场、试金石, 新闻学子的水平在这 场没有硝烟的新闻大战中展露无遗。反过来讲, 各级各 类媒体对新闻专业人才的不同需求促使高校新闻学专 
业培养目标的改进、完善与提升。高等院校对新闻学专 业人才的培养和媒体行业对新闻学人才的使用就好比 是一枚硬币的两个面, 两者是相辅相成、形影不离、互 相促进的。高等院校和媒体行业只有协调一致、共同发 展才能够培养出新闻传播行业真正需要的优秀人才。高 校新闻学专业人才的培养必须始终关注媒体行业的最 新发展状况, 两者必须紧密联系在一起, 协同创新、共 谋发展, 最终实现社会和谐进步、文化繁荣昌盛、人民 幸福美满的理想境界。

\section{3. 新闻学 “三位一体” 育人体系的构建}

\section{1. “三位一体” 育人体系的内涵}

新闻学 “三位一体” 育人体系中的 “三位” 指的 是思想政治教育、职业道德教育和专业知识教育, “一 体” 指的是合三为一、一体化协同发展。既然是构建 “三位一体” 育人体系、“三位一体”协同发展, 那么 就不存在孰轻孰重的问题。在整个新闻学专业育人体 系的构建过程中, 思想政治教育、职业道德教育和专 业知识教育始终是紧密融合在一起的, 始终是无法分 割、无法分离的。思想政治教育、职业道德教育和专 业知识教育等三项内容的教育就如同三项内容装在 同一个容器里, 无法将其中的一项内容单独分离出来, 具体新闻学专业育人体系示意图如图一所示。

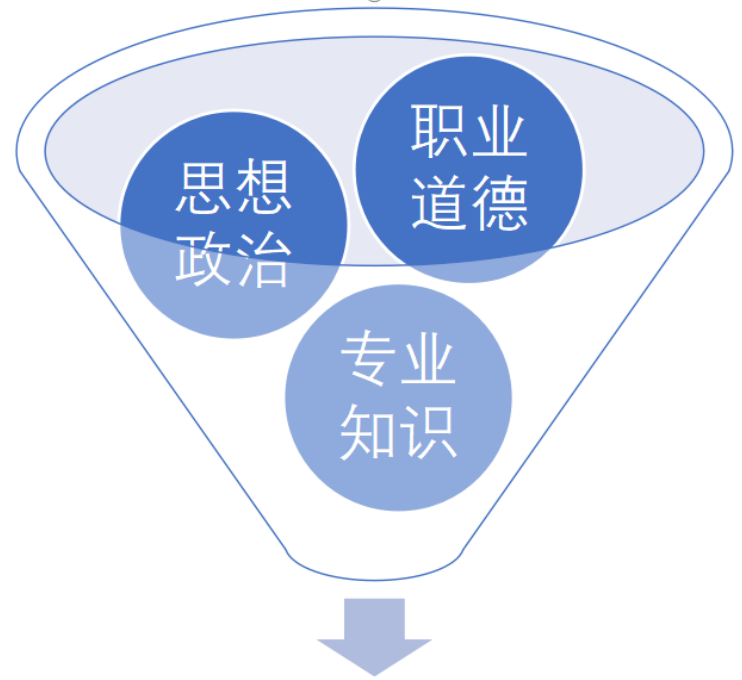

图 1 新闻学 “三位一体” 育人体系示意图

思想政治教育、职业道德教育、专业知识教育等 三项内容的教育是新闻学专业的学生必须接受的, 三 项教育的内容缺一不可, 它们共同构成了新闻学专业 育人体系的核心内容和组成部分。“三位一体” 育人 体系是新闻学专业人才培养的保障, 有了这样的保障 体系才能够培养出适应新闻出版行业发展需求的应 用型、复合型、专业性的优秀人才, 满足传媒行业对 人才的渴望与需求。

\section{2. “三位一体” 育人体系的实现}

既然思想政治教育、职业道德教育、专业知识教 育等三项教育内容缺一不可, 那么, 就需要在高等教 育教学过程中分门别类、分步实施、因材施教。针对 不同的教育群体、教育目标和教育内容, 由不同的教 育主体分别实施, 进行个性化培养。本文对思想政治 教育、职业道德教育和专业知识教育进行分别阐述。

\section{2. 1. 思想政治教育}

高等院校对新闻学专业的思想政治教育必须高 度重视。新闻学专业思想政治教育的实施, 应该以学 校的思政课教师为主导，专职辅导员、专业课教师发 挥辅助作用。思想政治教育最显著的体现为高校思想 政治理论课的开设与讲授。国内高校本科阶段必须开 设的思想政治理论课程主要包括《马克思主义基本原 理》《毛泽东思想和中国特色社会主义理论体系概论》 《中国近现代史纲要》《思想道德修养与法律基础》 《形势与政策》等。思想政治课程主要讲授马克思主 义基本原理、中国特色社会主义理论体系、中国近现 代发展的历史、中国共产党的发展史，还要讲授思想 道德与法治建设、国内外的发展形势、国内外的发展 政策等。因为思想政治理论课程主要由专职的理论课 教师讲授, 所以思政课理论教师在学生的思想政治教 育方面发挥了主导作用, 学校的相关管理人员、专职 辅导员、专业课教师等辅助进行, 共同对学生进行思 想政治教育。在思想政治教育的过程中，学生自身也 要发挥主体作用, 积极、主动地学习, 不断提升自己 的思想政治理论水平, 将来成为国家的栋梁之才, 为 社会主义的建设和发展贡献自己的力量。对学生的思 想政治教育来讲, 教师发挥的是引导作用、推动作用, 学生发挥的是主观能动性, 两者共同努力才能够更好 地促进思想政治教育的健康发展。

\subsection{2. 职业道德教育}

新闻学专业职业道德教育的实施, 应该以学校的 专职辅导员 (包括班导师、专职副书记等) 为主导, 相关管理人员和专业课教师发挥协同作用。新闻学专 业职业道德教育至少包括两个层面的内容: 第一层是 普遍的道德观念、价值观念教育。比如社会主义核心 价值观的教育, 个人层面要做到 “爱国、敬业、诚信、 友善”。“爱国” 就是对大学生进行爱国主义教育, 高 等学府培养出来的合格大学生首先要做到的是热爱 自己的祖国, 愿意为自己的祖国贡献自己毕生的心血, 愿意为祖国的发展添砖加瓦。不管在什么样的岗位上、 不管以后走到哪里, 大学毕业生都必须做到热爱祖国、 热爱人民。“敬业”就是要求大学生正视自己的身份, 在学校里努力学习, 不断提升自己的文化知识水平、 完善自己的文化知识结构。同时, 大学生还需要积极、 主动地认识社会、深入了解社会。通过各种方法、渠 道参与社会的发展和建设，提高自己的服务意识和服 务水平, 为以后走上工作岗位积累经验和知识储备。 
“诚信” 就是要求大学生牢固树立诚实守信的意识, 成为一个诚实守信的有用人才。不管是在大学校园里, 还是以后走上工作岗位, 都需要时刻提醒自己始终做 到诚实守信。“友善” 就是要求大学生严于律己、宽以 待人, 成为一个友好、善良的人。如果大家都能够友 善地与他人相处, 那么整个社会就会成为和谐发展的 社会，各项事业就会蒸蒸日上、蓬勃发展。

第二层是职业的、专业的道德观念、价值观念教 育。新闻学职业道德是新闻传播从业人员必须遵守的 道德规范。新闻传播从业人员必须在职业道德规范的 框架内从事新闻出版与传播活动。新闻传播从业人员 必须自觉遵循社会主义的 “党性原则”, 以“党性原 则” 指导自己的工作, 以 “党性原则” 引领自己的工 作。必须始终坚持 “为人民服务” “为社会主义服务” 的方针。新闻传播从业人员的出发点和立足点就是 “为人民服务” “为社会主义服务”, 创造出有利于人 民、有利于社会的优秀作品, 满足人民的精神文化需 求。本文以新闻报道为例进行分析, 新闻是新近发生 事实的报道, 新闻报道必须以事实为根据, 以事实为 准绳。新闻报道必须做到公正、公平、公开, 要做到 这些，就能够实现 “现象真实”与 “本质真实” 相统 一。坚持社会主义的“党性原则”, 坚持“为人民服务” “为社会主义服务” 的方针, 培养和树立职业的、专 业的道德观念、核心价值观念, 就能够培育出专业能 力强、职业素养高的优秀新闻传播人才。

第一层的普遍的道德观念、价值观念教育和第二 层的职业的、专业的道德观念、价值观念教育是相辅 相成的, 是缺一不可的。第一层道德观念、价值观念 教育是基础性的教育, 第二层职业的、专业的道德观 念、价值观念教育是高层次的教育, 是基础性的教育 的再提升。基础性的教育培育的是大学生做人的根本 理念和基本信条, 高层次的教育培育的是大学生的专 业素养和职业素质, 为大学生顺利毕业、走上媒体岗 位打下坚实的理论基础, 同时能够提升大学生媒体实 战技术能力。

\section{2. 3. 专业知识教育}

专业知识的核心是专业。毫无疑问, 新闻学专业 知识教育的实施必须以学校的专业课教师为核心。新 闻学专业思想政治教育、职业道德教育的实施, 专业 课教师发挥的是辅助作用与协同作用。新闻学专业课 教师可以通过 “课程思政” 的方式对学生进行思想政 治教育和职业道德教育。然而, 专业课程教师具有丰 富的、专业的新闻传播学相关知识, 专业知识教育、 专业知识传授、专业知识答疑等是专业课教师最擅长 的。专业知识教育最能够发挥新闻学教师的能力, 体 现新闻学教师的价值。

新闻学专业教师的职责就是 “传道、授业、解惑”, 将新闻传播学的基本知识、核心理论、主要技能等传授 给学生, 并且及时解答学生的疑惑, 全面提升学生的新 闻传播素养。本文从传统的课堂教学模式和互联网时代
新型的教学模式两个角度进行分析。传统的课堂教学模 式是教师进行专业知识教育的基本模式, 值得持续传承 下去。不管是小学、中学还是大学, 课堂教学都是最基 本、最核心的教学模式。传统课堂教学模式的最大特色 是教师的教与学生的学是在线下实体课堂中进行的, 课 堂是教学活动、师生交流、生生互动的主要场所。教师 通过课堂传授知识, 学生通过课堂获取知识、锻炼能力、 提升认知水平, 课堂教学占据了学生最主要的学习时间。 教师和学生在课堂中完成知识的传授任务, 共同丰富了 课堂教学的内涵, 创造了课堂教学的价值。

随着信息技术、通信技术、网络技术的不断发展与 成熟, 高校的教学活动中产生了一些新颖的教学模式, 互联网时代新型的教学模式对传统的课堂教学模式进 行了有益补充。比如翻转课堂教学模式、线上教学模式、 线上线下混合式教学模式等。翻转课堂教学模式将课堂 教学战线延伸了, 将教学设计成了课前一课中一课后。 课前以预习、视频学习为主, 课中以发言、讨论为主, 课后以总结、提升为主。翻转课堂教学模式大大拓展了 传统课堂教学的时间与功能, 激发了学生的学习兴趣, 提升了课堂教学的学习效果。线上线下混合式教学模式 则丰富了学生的学习路径, 丰富了教师的教学方法, 改 变了学生的学习方法。传统的课堂教学是线下的实体课 堂, 教师与学生面对面交流与互动, 面对面答疑。线上 线下混合式教学模式是线上自学与线下讲授相结合的 一种混合方法, 能够充分发挥线上线下各自的优势, 弥 补单一教学方法的不足之处, 调动学生的学习积极性, 最终提高教学与学习的效果。线下的实体课堂与线上的 虚拟课堂相结合, 共同完成专业知识的传授与获取教学 活动。线上教学模式属于完整意义上的互联网教学。借 助于互联网的线上教学是虚拟课堂, 学生可以看视频、 答题、提问，师生之间、生生之间可以在线交流、实时 互动, 整个教学过程可以完全在互联网上完成, 将互联 网的教学优势体现得淋漓尽致。

\section{4. 新闻学 “三位一体” 育人体系的完善}

从上述的研究发现，我们对新闻学思想政治教育、 职业道德教育、专业知识教育的分析与阐述，重点关 注的是高等院校的教育。新闻学专业思想政治教育的 实施, 是以学校的思想政治课教师为主导; 新闻学专 业职业道德教育的实施, 是以学校的专职辅导员 (包 括班导师、专职副书记等) 为主导; 新闻学专业知识 教育的实施，是以学校的专业课教师为核心。三项教 育的阐述均围绕高等院校教师展开，思政课教师、专 职辅导员、专业课教师等群体都属于高等院校内部的 专业人员。或者可以这样理解, 即新闻学“三位一体” 育人体系的构建是以人才培养为目标、以高等院校为 主体、以高校教师为核心、以课堂教学为主战场。整 个育人体系的构建均围绕高等院校展开, 没有扩展、 涉及到其他相关主体和相关人员。

但是, 新闻学专业思想政治教育、职业道德教育、 专业知识教育等 “三位一体” 育人体系的构建仅仅依 靠高等院校、高校教师、课堂教学是远远不够的, 需 要与时俱进、深入发展、不断完善。新闻学 “三位一 
体”育人体系的发展与完善需要社会、家庭的积极参 与, 需要学校教育、社会教育和家庭教育协同一致、 共同努力。有了社会、家庭的共同参与，高校、社会、 家庭等三种力量、三个维度就可以构建完善的新闻学 “三位一体” 育人体系。在专业知识教育方面, 高等 院校、新闻学专业教师具有一定的权威性、可信型、 便利性, 能够给予学生一定的指导和引导。然而, 新 闻学专业的思想政治教育、职业道德教育则离不开社 会教育和家庭教育的广泛参与。

\section{5. 结论}

整个社会具有一定的运行规则和大家都必须遵 守的运行规律, 新闻学专业的学生也必须遵守。家庭 教育对学生的影响是巨大的、深远的、广泛的, 家庭 的潜移默化作用往往能够影响一个人的终生。因此, 新闻学 “三位一体” 育人体系的构建, 育人体系的未 来发展与不断完善, 需要高等院校、整个社会和每个 家庭的共同努力，需要发挥协同的力量。

\section{项目基金}

本文为以下项目的研究成果: 浙江省高等教育 “十三五” 第二批教学改革研究项目《融媒体背景下 数字编排技术课程混合式立体型教学模式改革研究》 (项目编号: jg20190581); 浙大宁波理工学院教学研 究与改革项目《新闻传播学 “三位一体” 育人体系研 究》(项目编号: NITJG-201910); 浙江省线上线下混 合式一流课程《数字出版》; 浙大宁波理工学院第二 批校级一流课程《数字出版》 (项目编号: NITJG202060)。

\section{REFERENCES}

[1] Wang, X. (2020) The connotation, characteristics, difficulties and coping strategies of curriculum ideology and politics in the new era.Journal of Xinjiang Normal University (Philosophy and Social Sciences Edition)., 41: 50-58.

[2] Zhao, J.(2019) "Curriculum Ideological and Political": Meaning, Ideas, Problems and Countermeasures.Journal of Hubei University of Economics., 17: 114-119.

[3] Shi, S. (2018)Correctly grasp the relationship between "curriculum ideological and political" and ideological and political courses.Ideological and Theoretical Education., 11: 57-61.

[4] Yang, X. (2018)Higher Education "Three Comprehensive Education": Theoretical Implications, Realistic Problems and Practical Paths.China Higher Education., 18: 4-8.

[5] Tan, X.(2018) An analysis of the value connotation and practical path of curriculum ideology and politics. Ideological and Political Work Research., 4: 44-45.

[6] Wu, Y. (2018)On the three focal points of colleges and universities to promote "curriculum ideological and political".School Party Building and Ideological Education., 1: 67-69.

[7] Gao, Y.(2017) The key issues and solutions of curriculum ideological and political construction.China Higher Education., 3: 11-14.

[8] Li, G. (2017)Curriculum ideological and political construction must firmly grasp the five key links. China Higher Education., 3: 28-29.

[9] Qiu, W. (2017)The value meaning and generation path of curriculum ideology and politics.Ideological and Theoretical Education., 7: 10-14.

[10] Gao, D.(2017) Curriculum ideology: the inevitable choice to effectively play the role of the main channel of classroom education.Journal of Ideological and Theoretical Education, 1: 31-34.

[11] Tao, W.(2017)Research on the practice of vocational education talent training based on craftsman spirit. Vocational Education Forum., 2: 60-64.

[12] Zeng, L.(2017)The "double innovation" strategy of university innovation and entrepreneurship education services requires coordinated development.Educational Research., 38: 70-76+105.

[13] Gao, D. (2017)From ideological and political courses to curriculum ideological and political: constructing the curriculum system of ideological and political education in colleges and universities from a strategic height. China Higher Education., 1: 43-46.

[14] Hao, J.(2016) The construction and enlightenment of American innovation and entrepreneurship education system. Research in Higher Education of Engineering., 2: 7-12.

[15] Cao, P.(2015)Looking at the basic ideas of mathematics from the core literacy of the subject and the value of subject education. Curriculum. Textbook. Teaching Method., 35: 40-43+48.

[16] Tian, H.(2015)Implementing the fundamental task of Lide Shuren, comprehensively deepening the curriculum teaching reform. Curriculum. Textbook. Teaching Method., 35: 3-8.

[17] Zhao, P.(2014)The practice and understanding of modern apprenticeship training. China Vocational and Technical Education., 21: 150-154.

[18] Liu, Y.(2014)On strengthening the education of college students' socialist core values under the new 
situation. Journal of Ideological and Theoretical Education., 5: 106-109.

[19] Luo, Y.(2013)The realization path and effective mechanism of "Lide Shuren". Ideological Education Research., 7: 45-49.

[20] Fang, X.(2013)Theoretical guidance and practical path of "Leading morality and cultivating people" in colleges and universities. Journal of Ideological and Theoretical Education., 6: 94-98.

[21] Zhao, P.(2013)The practice and thinking of "modern apprenticeship". China Vocational and Technical Education., 12: 38-44.

[22] Chen, Y. (2013)Lide Shuren: The Fundamental Task of Contemporary College Students' Ideological and Political Education. Journal of Ideological and Theoretical Education., 4: 9-14.

[23] Wang, X.(2013)Innovation and Development: Ideological and Political Education in Colleges and Universities from the Perspective of New Media Environment. Ideological Education Research., 2: 78-80. 